Jacek Goclon

\title{
Działalność gabinetu Leopolda Skulskiego w świetle protokołów posiedzeń Rady Ministrów (13 XII 1919 - 9 VI 1920) i rola rządu w okresie przygotowań do „wyprawy kijowskiej"
}

\begin{abstract}
SUMMARY
Activities of the cabinet of Leopold Skulski on the basis of the minutes of the Council of Ministers' Meetings (13th December 1919 - 9th June 1920) and the role of the government in the period of preparations for the Kiev offensive

The government of Leopold Skulski had been active under the pressure of war preparation but was mainly occupied by internal issues. Foreign policy was under the control of the country's leader, Marshal J. Piłsudski. The cabinet of Leopold Skulski had little roomfor maneuver, the expenses connected with the war campaign represented $60 \%$ of the country's total budget. Even though war orders had a very positive influence on industrial and agricultural output growth, the bulk of that output had been absorbed by the army, which automatically created problems in the open market. Similarly, the country's foreign trade balance was significantly overloaded by the burden of military expenditure with inflation providing a source of solid revenue income for covering war expenses. The Skulski government tried to stabilize the internal balance; on 1 April 1920 it unified the various state treasury and taxation systems and on 29 April, it unified the country's five currencies into a single currency. On 1 June, a unified railway tariff covering the whole country was introduced. During the activity of this government, parliament had to agree an eight hour working day and a 46 hour working week for the workers, as well as providing them with a social security system.
\end{abstract}

Key words: Józef Piłsudski, Kiev campaign, agricultural policy, unification of local currency; standard price tariff for railway connections

Słowa kluczowe: Józef Piłsudski, wyprawa kijowska, polityka rolna, unifikacja waluty lokalnej, jednolita taryfa kolejowa

Rząd Leopolda Skulskiego został powołany 4 grudnia 1919 roku i funkcjonował około pół roku. W tym czasie nastąpiła pamiętna „wyprawa na Kijów”; nasuwa się więc pytanie, jaką rolę odegrał ten gabinet w przygotowaniach - do 
tej tak bardzo brzemiennej w skutkach dla narodu i państwa polskiego - operacji militarnej, jaką było wkroczenie Wojska Polskiego na Ukrainę. Stąd podjęcie tego tematu wydaje się w pełni zasadne, szczególnie dla ukazania działalności tego rządu na tle ówczesnej „polityki wschodniej”, kierowanej przez Naczelnika Państwa i Naczelnego Wodza - Józefa Piłsudskiego.

Podstawę opracowania (które ma charakter źródłowy) stanowiły głównie - zespoły archiwalne w Archiwum Akt Nowych w Warszawie, źródła drukowane, relacje pamiętnikarskie i prasowe oraz opracowania ${ }^{1}$.

\section{Powołanie gabinetu Leopolda Skulskiego}

Należy przypomnieć, że premier ustępującego rządu, Ignacy Paderewski, podał się do dymisji na początku grudnia 1919 roku (przyjętej przez Naczelnika Państwa 9 grudnia 1919 roku), lecz rozmowy nad utworzeniem nowego gabinetu toczyły się już dużo wcześniej, bo późną jesienią 1919 roku, kiedy to L. Skulski rozpoczął międzypartyjne mediacje jedynie w sprawie rekonstrukcji rządu I. Paderewskiego ${ }^{2}$, ale Wincenty Witos poradził Skulskiemu, „aby zamiast bezskutecznych zabiegów około tworzenia cudzego rządu, podjął się własny rząd utworzyć, jako najbardziej powołany i dorastający do wytworzonej sytuacji"

Mediacje nad utworzeniem nowego gabinetu rozpoczęły się w nocy z 10 na 11 grudnia. Po wielogodzinnej dyskusji osiągnięto porozumienie w sprawie przyszłej konstytucji (co do wyboru prezydenta przez dwuizbowy parlament i sposobu dokonania parcelacji, wykupu lasów oraz określając maksimum posiadania gruntów) ${ }^{4}$. W dniu 11 grudnia 1919 roku konwent senio-

1 Autor świadomie, w tak dużym zakresie, cytował protokoły posiedzeń Rady Ministrów - dla bardziej szczegółowego przybliżenia ich przebiegu. O postaci premiera L. Skulskiego zob. Ł. Kot, Leopold Skulski. Premier z Zamościa 1877-1939, Zamość 2007; D. Kaszczyk-Grodzicka, Farmaceuta łódzki Leopold Skulski, polityk, społecznik i mą̇ stanu II Rzeczypospolitej Polskiej, "Wędrownik” 1990, nr I-III; Kto był kim w Drugiej Rzeczypospolitej, red. J. M. Majchrowski, t. 1, Warszawa 1994; Polski słownik biograficzny, Warszawa 1990; M. Jaskólski, Władze administracyjne Łodzi do 1939 roku, Łódź 2001, s. 12 i nast.

2 Cyt. za: A. Kosicka, Gabinet Paderewskiego, [w:] Gabinety Drugiej Rzeczypospolitej, red. J. Faryś, J. Pajewski, Szczecin - Poznań 1991, s. 51; por. Sprawozdanie Stenograficzne posiedzenia Sejmu (105), 18.12.1919.

3 Objęcie przez Leopolda Skulskiego stanowiska premiera nie było specjalnym zaskoczeniem dla polityków, bowiem miał on już w gabinecie I. Paderewskiego objąć stanowisko ministra spraw wewnętrznych, czemu skutecznie sprzeciwił się J. Piłsudski, J. Goclon, Rząd Ignacego Paderewskiego. Geneza, skład osobowy i działalność (16.01 - 9.12.1919 r.), „Acta Universitatis Lodziensis, Folia Historica" 2011, 85, s. 93-145; idem, Rząd Leopolda Skulskiego (13 XII 1919 - 9 VI 1920), skład, działalność i jego polityka wschodnia (zarys problemu), „Acta Universitatis Lodziensis, Folia Historica” 2012, 88, s. $177-202$.

4 Do polityków, którzy wówczas odegrali pierwszoplanową rolę w tworzeniu nowego gabinetu, należeli: Maciej Rataj, Wincenty Witos, Leopold Skulski i Edward Dubanowicz. Jesienią 1919 r. 
rów zatwierdził kandydaturę L. Skulskiego na stanowisko prezesa Rady Ministrów. Przeciwny tej kandydaturze był klub Polskiej Partii Socjalistycznej (który na stanowisko premiera zamierzał zgłosić Stanisława Wojciechowskiego); brak większego zainteresowania wykazał natomiast Klub Pracy Konstytucyjnej. W tym samym dniu Józef Piłsudski powierzył L. Skulskiemu formowanie nowego gabinetu. Warto przytoczyć opinię przywódcy PSL-„Piast”, Wincentego Witosa, o nowo mianowanym prezesie Rady Ministrów, według którego „szef rządu, p. Skulski, był bezsprzecznie człowiekiem bardzo zdolnym, przygotowanym praktycznie jak mało kto w Polsce, mającym jak najlepsze chęci, panowało też ogólne przekonanie, że wkrótce potrafi naprawić błędy swojego poprzednika, usunie rozprzężenie, wprowadzi porządek, rozpocznie wszechstronną, celową pracę. $Z$ dużą przychylnością traktowała ten rząd i lewica, zadowolona, że p. Skulski wyłamał się spod wpływów Narodowej Demokracji. Tymczasem niezadługo przyszła przez nikogo nie przewidziana niespodzianka. Premier bardzo rychło uległ p. Piłsudskiemu, stając się jego prawie bezwolnym narzędziem. Była to sprawa bardzo wielkiej wagi, która mogła zaniepokoić wszystkich poważnych polityków ze względu na zamierzenia Naczelnika Państwa"5. Należy jednak podkreślić, że kierowanie rządem przez L. Skulskiego (polityka wówczas stosunkowo mało znanego) przypadło na bardzo ciężkie czasy; trudności aprowizacyjne, spadek produkcji, wzrost bezrobocia i ciągłe spory polityczne $\mathrm{w}$ parlamencie ${ }^{6}$.

doszło do koalicji partii centrowych z ugrupowaniami ludowymi, co pozwoliło na powołanie nowego rządu; większość sejmową stworzyło PSL i Narodowe Zjednoczenie Ludowe (liczące 72 posłów), przy nieformalnym poparciu przez Narodowy Związek Robotniczy, Narodowo-Chrześcijański Klub Robotniczy i Zjednoczenie Mieszczańskie. Natomiast do tej koalicji nie wszedł Związek Ludowo-Narodowy (do którego należało, do połowy 1919 r., wielu posłów, lecz którzy do grudnia przeszli do ww. klubów). Z tym że wkrótce posłowie, należący przedtem do PSL "Wyzwolenie”, ponownie opuścili PSL, rozczarowani ustępstwami w sprawach reformy rolnej, ibidem, s. 179; A. Wątor, Gabinet Leopolda Skulskiego, [w:] Gabinety Drugiej Rzeczypospolitej, s. 55; zob. idem, Gabinet Leopolda Skulskiego, [w:] Od Moraczewskiego do Składkowskiego. Gabinety Polski Odrodzonej 1918-1939, red. J. Faryś, A. Wątor, H. Walczak, Szczecin 2010 (publikacja ta jest właściwie powtórzeniem ww.), s. 53-63.

5 Dalej w swoich wspomnieniach późniejszy trzykrotny premier W. Witos tak pisał: „Ówczesna polityka p. Piłsudskiego polegała jakoby na zamiarze utworzenia osobnych państw: ukraińskiego i białoruskiego, które by oddzielały Polskę od Rosji i weszły z Polską w stałą unię państwową. Mogło się to stać dopiero wówczas, gdyby Rosja bolszewicka została pokonana i zmuszona do ustąpienia z obszarów mających stanowić te nowe państwa. Stronnictwa prawicowe tej kombinacji były stanowczo przeciwne, nie chcąc narażać Polski na uciążliwą, kosztowną i pewną wojnę, jak również na możliwą utratę własnych, znacznych terenów, do nowych tworów państwowych przydzielić się mających. Wyrażały przy tym obawę, że państwa utworzone kosztem Polski mogą się stać dla niej samej w przyszłości niebezpieczne" i trudno się z tymi obawami nie zgodzić, W. Witos, Moje wspomnienia, t. II, cz. 2, Warszawa 1990, s. 56, 63. Znamienne, że do swojego gabinetu premier nie wprowadził żadnego polityka z własnego ugrupowania politycznego, tj. Narodowego Zjednoczenia Ludowego, A. Wątor, op. cit., s. 56; A. Paczkowski, Leopold Skulski, premier Republiki Polskiej 13 X 1919 - 9 VI 1920, [w:] Prezydenci i premierzy Drugiej Rzeczypospolitej, Wrocław 1992, s. 116.

6 Leopold Skulski, z wykształcenia inżynier chemik, absolwent Technische Hochschule w Karlsruhe 


\section{Działalność rządu}

Na wstępie należy przypomnieć, w jakiej sytuacji nowy gabinet przejmował kierowanie państwem; sprawą podstawową stawała się polityka zagraniczna, a szczególnie relacje z bolszewicką Rosją, z którą Rzeczpospolita trwała w konflikcie zbrojnym (choć nieformalnym) od lutego 1919 roku, kiedy to na Wołyniu rozpoczęły się pierwsze starcia zbrojne, z początkowo dość szybko posuwającą się w kierunku zachodnim Armią Czerwoną. Jednak po pierwszych przegranych nieliczne oddziały bolszewickie rozpoczęły odwrót (i to bez większych walk), w wyniku czego latem 1919 roku Wojsko Polskie doszło aż do Berezyny, która na długo stała się linią frontu. Jednak z końcem tego roku naczelne dowództwo Wojska Polskiego zaczęło zdawać sobie sprawę z zagrożenia ze strony Armii Czerwonej. Sprawnie działający polski wywiad donosił o coraz większej koncentracji wojsk bolszewickich. W tym samym czasie rosyjski komisarz spraw zagranicznych, Gieorgij Cziczerin, rozsyłał liczne depesze - do rządów wielu państw świata - o "pokojowych intencjach” Moskwy, ale były to tylko puste hasła propagandowe, mające na celu zyskanie na czasie w celu lepszego przygotowania Armii Czerwonej do uderzenia na Polskę i nawet przez chwilę

(1902-1906), obejmował urząd premiera w wieku 43 lat. Wcześniej mieszkał w Łodzi, gdzie miał aptekę. Działalność społeczną rozpoczął tuż przed wybuchem pierwszej wojny światowej. Współorganizował oddział Sokoła w Łodzi, w 1915 wstąpił do Zjednoczenia Narodowego, a rok później do Ligi Narodowej, w 1917 r. wybrany do łódzkiej Rady Miejskiej, obejmując stanowisko burmistrza (do lutego 1919 r.). W rządzie L. Skulskiego teki ministerialne objęli: ministerstwo spraw wewnętrznych - ponownie Stanisław Wojciechowski, który resortem tym kierował w poprzednim rządzie I. Paderewskiego (studiował na Wydziale Fizyko-Matematycznym Cesarskiego Uniwersytetu Warszawskiego, działacz na rzecz rozwoju spółdzielczości; dyrektor Związku Spożywców, wykładowca spółdzielczości, na stanowisku profesora, w warszawskiej Wyższej Szkole Handlowej i Szkole Głównej Gospodarstwa Wiejskiego; w 1. 1922-1926 prezydent RP); sprawy zagraniczne - Stanisław Patek, prawnik (od 16 grudnia - przez kilka dni jako kierownik tego resortu - Władysław Wróblewski, prawnik, po drugiej wojnie światowej profesor Uniwersytetu Łódzkiego); sprawy wojskowe - gen. Józef Leśniewski (zawodowy oficer carskiej armii); skarb - Władysław Grabski (studiował w Ecole Libre des Sciences Politiques (1892-1894), historię i ekonomię na Sorbonie (1893-1895) oraz rolnictwo na Uniwersytecie w Halle (1896-1897), rektor warszawskiej SGGW w 1. 1926-1928); Antoni Olszewski, minister przemysłu i handlu (inżynier); rolnictwo Franciszek Bardel (adwokat; początkowo studiował przez dwa lata teologię, a następnie filozofię i prawo na UJ; resort rolnictwa objął z rekomendacji PSL-„Piast”, w którym był wiceprezesem Zarządu Głównego); resort aprowizacji - Stanisław Śliwiński (inżynier rolnik, działacz gospodarczy i społeczny); robót publicznych - Andrzej Kędzior (działacz PSL); pracy - Edward Pepłowski (inżynier); kolei - Kazimierz Bartel (profesor geometrii wykreślnej Politechniki Lwowskiej i jej rektor po zakończeniu kariery politycznej; pięciokrotny premier w II RP); ministerstwo poczty i telegrafów - Ludwik Tołłoczko (inżynier elektryk); sprawiedliwości - Jan Hebdzyński (adwokat); wyznań religijnych i oświecenia publicznego - Tadeusz Łopuszański (nauczyciel gimnazjalny, matematyk, działacz na rzecz reformy pedagogiki); zdrowia - Witold Chodźko, jako kierownik ministerstwa (lekarz psychiatra i neurolog, profesor higieny) oraz ministerstwo byłej dzielnicy pruskiej - Władysław Seyda (adwokat, studiował prawo i ekonomię na niemieckim Uniwersytecie Wrocławskim). Analiza dróg życiowych szefów resortów pokazuje, że byli to politycy w większości przygotowani zarówno wykształceniem (choć nie w każdym przypadku kierunek studiów miał cokolwiek wspólnego z profilem resortu), jak i praktyką zawodową - do kierowania ministerstwami, A. Paczkowski, op. cit. 
nie powstrzymywało to napływu kolejnych rosyjskich dywizji na linię frontu? Naczelny Wódz zaczął rozważać rozpoczęcie wojny, trafnie przewidując, że rosyjska ofensywa jest już tylko kwestią czasu.

Należy podkreślić, iż znaczna część polityków endeckich nie popierała rozprawy militarnej z bolszewicką Rosją, czemu dano wyraz w sejmowej komisji spraw zagranicznych (której przewodniczył Stanisław Grabski, brat późniejszego premiera Władysława Grabskiego), gdzie usiłowano przeszkodzić realizacji zamiarów Piłsudskiego. Wywołało to ostre spory polityczne, w co został wciągnięty sam premier L. Skulski oraz minister spraw zagranicznych, S. Patek. Spory parlamentarne zaogniały, przynajmniej pośrednio, „pokojowe” propozycje Moskwy, w których szczere intencje niektórzy posłowie, zwłaszcza endecy, byli nawet skłonni uwierzyć, ale Piłsudski pozostał nieugięty; uważał, że oderwanie Ukrainy od Rosji - to jedna z najważniejszych spraw w polskiej polityce zagranicznej!!

Jednak sprawy te nie zajmowały nowego gabinetu i na jego pierwszym posiedzeniu 15 grudnia 1919 roku szef rządu zawiadomił zgromadzonych ministrów o swoim najbliższym wystąpieniu na forum Sejmu. Następnie rząd przyjął wniosek MSW w sprawie „zwolnienia z obozów internowanych tych wszystkich Polaków, Ukraińców i Żydów ze wschodniej Galicji, których internowano za czyny polityczne", ustalił także, że posiedzenia gabinetu będą odbywać się dwa razy w tygodniu (w poniedziałki i czwartki) oraz utrzymał „W mocy uchwały Rady Ministrów z 1-go oraz 26-go sierpnia 1919 r. w sprawie utworzenia Rady Gospodarczej, złożonej z pp. Ministrów: Skarbu, Rolnictwa i Dóbr Państwowych, Przemysłu i Handlu, Aprowizacji, Kolei Żelaznych i Spraw Wojskowych, oraz p. Ministra b. Dzielnicy Pruskiej"9.

7 W. Gostyńska, Materialy archiwalne o tajnych rokowaniach polsko-radzieckich w Baranowiczach i Białowieży, „Z dziejów stosunków polsko-radzieckich", nr 4, Warszawa 1969; W. Pobóg-Malinowski, Najnowsza historia polityczna Polski, t. 2 (1914-1939), Warszawa 2000, s. 405; W. Suleja, Józef Piłsudski, Wrocław 1997, s. 211, 214-215; N. Davies, Orzet biały Czerwona gwiazda. Wojna polsko-bolszewicka 1919-1920, Kraków 1997, s. 97; S. Kutrzeba, Polska Odrodzona 1914-1939, Kraków 1988, s. 135; zob. też: T. Teslar, Polityka Rosji Sowieckiej podczas wojny z Polska: trzy momenty, Warszawa 1937, s. 21 i in.; J. C. Malinowski, Zarys myśli politycznej Józefa Piłsudskiego, Kraków 1989, s. 32 i in.; W. Jędrzejewicz, Rokowania borysowskie w 1920 roku, „Niepodległość", t. 3, Londyn 1951; J. Lewandowski, U źródet wyprawy kijowskiej, „Zeszyty Naukowe WAP” 1962, nr 7; J. Sieradzki, Białowieża i Mikaszewicze. Mity i prawdy. Do genezy wojny pomiędzy Polska a RSFRR w 1920 r., Warszawa 1959, s. 27 i nast.

8 J. Topolski, Historia Polski, Warszawa 1994, s. 254; J. Pajewski, Stanistaw Patek (16 XII 1919 - 9 VI 1920 r.), [w:] Ministrowie Spraw Zagranicznych (1919-1939), red. J. Pajewski, Szczecin 1991; A. Paczkowski, op. cit., s. 119; A. Wątor, op. cit., s. 57; J. Goclon, Rząd Leopolda Skulskiego..., s. 180-184.

9 Przyjęto także „projekt ustawy o przedłużeniu terminów przedawnienia oraz przedstawienia do zapłaty kuponów procentowych, rentowych i dywidendowych na terytorium b. Dzielnicy Pruskiej oraz projekt amnestii przy przekroczeniach przepisów o państwowych podatkach i opłatach stemplowych, obowiązujących na terenie b. Dzielnicy Pruskiej, upoważniając zarazem p. Ministra b. Dzielnicy Pruskiej do wniesienia tych obu projektów ustaw w trybie nagłym do Sejmu"; przyjęto również „wniosek Ministerstwa Spraw Wewnętrznych w sprawie zwolnienia z obozów internowanych tych wszystkich Polaków, Ukraińców i Żydów ze wschodniej Galicji, których internowano za czyny polityczne"; rząd postanowił także "utrzymać nadal w mocy uchwały" - 
Na kolejnych dwóch posiedzeniach grudniowych (17 i 22, również pod przewodnictwem premiera) omawiano: „projekt sejmowego exposé premiera"10, kwestię „wyznaczenia kwoty 500.000 marek na studia dla pogłębienia Wisły i budowy portu w Tczewie”, sprawę "nabycia przez państwo floty handlowej”, ,"wypuszczenia w obieg znaków pieniężnych (bonów) w walucie koronowej po 1000 koron sztuka”, ,przyjęto wniosek p. Ministra Grabskiego o dodatkowe upoważnienie P.K.K.P. do emitowania dalszych 3 miliardów marek polskich, które zostały już częściowo puszczone w obieg, a na które nie ma upoważnienia Sejmu Ustawodawczego" oraz "przyjęto projekt ustawy o rozszerzeniu właściwości sądów pokoju w byłym zaborze rosyjskim"11.

Styczniowe posiedzenia gabinetu $(5,8,10,12,16,17,19,22,24,26$ stycznia - wszystkie pod przewodnictwem premiera) były widownią ożywionych dyskusji m.in. w takich sprawach, jak: „strajk kolejowy we Lwowie”, „projekt ustawy w przedmiocie ustanowienia marki polskiej prawnym środkiem płatniczym na całym obszarze Państwa Polskiego" (jednocześnie „minister skarbu cofnął swój projekt ustawy w przedmiocie wypuszczenia przez P.K.K.P. biletów w walucie koronowej"), ", projekt ustawy w przedmiocie zmiany niektórych postanowień ustaw karnych", komunikat „o katastrofalnym stanie zapasów węgla na kolejach", wnioski nominacyjne na stanowiska sędziowskie, kwestia zakupu

gabinetu Ignacego Paderewskiego - „w sprawie utworzenia Rady Gospodarczej, złożonej z pp. Ministrów: Skarbu, Rolnictwa i Dóbr Państwowych, Przemysłu i Handlu, Aprowizacji, Kolei Żelaznych i Spraw Wojskowych, oraz p. Ministra b. Dzielnicy Pruskiej", Archiwum Akt Nowych w Warszawie, Prezydium Rady Ministrów (dalej: AAN, PRM), mf. 20052, t. 8, pagina (dalej: p.) 524,525 .

10 Swoje exposé premier wygłosił w Sejmie trzy dni później; rozpoczął je od oddania zasług swojemu poprzednikowi, Ignacemu Paderewskiemu, stwierdzając: „Uchybiłbym z pewnością swoim obowiązkom gdybym obejmując kierownictwo Rady Ministrów Rzeczypospolitej nie zaczął od wyrazów wysokiej czci i uznania mojemu znakomitemu poprzednikowi Ignacemu Paderewskiemu. [...] Z Ignacym Paderewskim ustąpił z urzędu - miejmy ufność, że nie z dalszej pracy dla dobra Ojczyzny - człowiek, którego nazwisko najdalsza potomność wymieniać będzie jako jedno z najczystszych, najszlachetniejszych, najwięcej zasłużonych w Polsce" (cyt. za: A. Paczkowski, op. cit., s. 115). Następnie nowy premier przedstawił podstawowe założenia przyszłej polityki rządu, szczególnie akcentując potrzebę uchwalenia konstytucji, przeprowadzenie reformy rolnej i polepszenie aprowizacji całego kraju. Omówił także sprawy polityki finansowej i ustawodawstwa pracy. Zasadniczo, podzielał linię polityczną swojego poprzednika, szczególnie w zakresie polityki zagranicznej, czym uzyskał akceptację większości klubów sejmowych, ale trudności przed jakimi stanął rząd nie wróżyły rychłej realizacji zapowiedzianych celów. Na tym posiedzeniu minister skarbu W. Grabski zgłosił „projekt ustawy o Radzie Finansowej”, z wnioskiem „o uchwalenie w trybie nagłym”, jednak spotkał się z dość nieoczekiwanym oporem, ponieważ zdaniem premiera „konwent seniorów wypowiedział się za odmiennym załatwieniem tej sprawy, a mianowicie za wyłonieniem z komisji skarbowo-budżetowej specjalnego komitetu, który by znajdował się w ścisłym kontakcie z Ministrem Skarbu i od którego uzyskiwałby on uprzednią aprobatę na takie zarządzenia i projekty finansowe, które muszą być uchwalone i zaaprobowane przez Sejm w szybkim tempie”, ponieważ, dodał premier, „utworzenie tej Rady Finansowej na podstawie ustawy mogłoby w przyszłości zbytnio krępować Ministra Skarbu. Wobec podniesionych przeciw temu projektowi wątpliwości p. Minister Grabski cofnął go", AAN, PRM, p. 531.

11 AAN, PRM, p. 570, 571. 
fabryki na Pradze przez Ministerstwo Poczt i Telegrafów (za 2650000 marek polskich) ${ }^{12}$, czy burzliwa dyskusja nad „pokojową propozycją” ze strony rządu bolszewickiej Rosji „o nawiązaniu rokowań z dnia 22 grudnia 1919 r., które Ministerstwo Spraw Zagranicznych otrzymało drogą radiotelegraficzną dnia 29 grudnia 1919 r.” (rząd uznał, że „powzięcie rozstrzygnięcia, co do tych propozycji będzie dopiero możliwe po zebraniu materiału informacyjnego, które jest w toku" $)^{13}$. Należy przypomnieć, że rząd nie cieszył się w tym czasie zbytnim uznaniem tak prasy, jak i innych środowisk i stąd „,w kwestii stosowania przepisów prasowych i cenzury sztuk teatralnych oraz filmów uznano za wskazane prosić p. Ministra Spraw Wewnętrznych, by wydał zarządzenia należytej ochrony pp. Ministrów i członków Rządu przed grubiańskim ośmieszaniem i deprecjonowaniem władzy, zwłaszcza w teatrach, podczas gdy p. Prezydent zwróci stosowną uwagę reprezentantom prasy na najbliższej konferencji"14.

Rząd absorbowały też sprawy przejęcia kolejnictwa na terenie Wolnego Miasta Gdańska przez władze polskie; „chodziło o to, aby w okresie przejściowym między wejściem w życie traktatu a zawarciem konwencji między Polską a Wolnym Miastem Gdańskiem, Rząd polski mógł już objąć zarząd tymi kolejami, względnie uzyskać pewną ingerencję w sprawy tego zarządu"; w tej sprawie przyjęto „wniosek Min. Kolei żelaznych o podjęcie natychmiast kroków przygotowawczych w kierunku przejęcia już w określonym powyżej czasie przejściowym, zarządu kolejami na terenie Gdańska przez władze polskie". Jednocześnie premier oświadczył, że „zamierza co miesiąc urządzać konferencje $\mathrm{z}$ przedstawicielami prasy $\mathrm{w}$ celu informowania ich periodycznie o wynikach działalności Rządu i prosi pp. Ministrów, by zechcieli dostarczać materiałów do tych konferencji w postaci wywiadów, które będzie od nich zbierał Naczelnik Wydziału Prasowego Prezydium Rady Ministrów". Ministrowie wy-

12 Na tym samym posiedzeniu „,na wniosek nagły p. Ministra Aprowizacji Rada Ministrów udzieliła zezwolenia na wywóz do Anglii 6.000 ton cukru i 5.000 ton krochmalu, jako zadatku na zapłacenie kosztów przywozu nawozów sztucznych", AAN, PRM, mf. 20053, p. 2.

13 Pierwszą próbą nawiązania kontaktów między obydwoma rządami był telegram G. Cziczerina z 27 listopada 1918 r., w którym zaproponował wzajemne powołanie przedstawicielstw dyplomatycznych. Pierwsza propozycja zawarcia "trwałego pokoju” została przez G. Cziczerina wystosowana pod adresem polskiego rządu 22 grudnia 1919 r. i z formalnego punktu widzenia była nie do przyjęcia, ponieważ bolszewicki komisarz (minister) występował nie tylko w imieniu władz radzieckich, ale także w imieniu... polskich organizacji robotniczych! Drugą wysłano 28 stycznia 1920 r. (także pełną pustych frazesów). Obydwie - w sytuacji coraz większej koncentracji wojsk rosyjskich na linii rozejmowej - pozostały oczywiście bez odpowiedzi, Księga Czerwona. Zbiór dokumentów dyplomatycznych o stosunkach Rosji i Polski od 1918 do 1920 r., Moskwa 1921, s. 14; T. Żenczykowski, Dwa komitety 1920 1944: Polska w planach Lenina i Stalina: szkic historyczny, Warszawa 1990, s. 19, 21 (tutaj podano datę ogłoszenia odezwy - 2 lutego); J. Goclon, W obronie Europy. Wojna z bolszewicka Rosja w 1920 roku, Komorów 2012, s. 64 i in.; P. Zaremba, Historia Dwudziestolecia (1918-1939), t. 1, Paryż 1981, s. 160 (tutaj data odezwy - 5 lutego), s. 162-166 i in.; AAN, PRM, mf. 20053, p. 25.

14 AAN, PRM, mf. 20053, p. 25. 
czuwali, że wzajemne informacje między resortami są potrzebne i w tej sprawie wystąpił minister Bartel, który stwierdził, że „byłoby wskazanym, by raz na miesiąc pp. Ministrowie informowali się wzajemnie o wynikach działalności swoich Ministerstw i by tym krótkim sprawozdaniom bywało poświęcone jedno posiedzenie Rady Ministrów co miesiąc"15.

Kolejne sprawy, które rozpatrywał rząd na styczniowych posiedzeniach to: przyjęcie "projektu ustawy w przedmiocie dalszej emisji biletów Polskiej Krajowej Kasy Pożyczkowej”, przyjęcie wniosku „w sprawie ustanowienia w Małopolsce komisarzy dla strzeżenia granic przed przemycaniem towarów, w szczególności niestemplowanych koron”; przyznano, „począwszy od 1-go stycznia (1920 r.) wszystkim urzędnikom i funkcjonariuszom państwowym, nauczycielom szkół powszechnych, państwowych szkół średnich i szkół wyższych nadzwyczajny dodatek drożyźniany miesięczny”, a „po dłuższej dyskusji przyznano [...] ten dodatek, w tej samej wysokości i na tych samych zasadach, co dla urzędników i funkcjonariuszy państwowych" pracownikom kolejowym, ustalono "dla urzędników jako minimum pracy 7 godzin dziennie, nie wyłączając soboty, z tym że wypełnienie tego minimum nie uwalnia w razie wymogów służby od bezwzględnego obowiązku pracy i poza tymi godzinami urzędowymi bez osobnego wynagrodzenia. Tym samym - czytamy w stenogramie posiedzenia rządu - wszelkie dodatkowe zajęcia zarobkowe w zasadzie są wykluczone i mogą być dozwolone przez władzę przełożoną tylko w zupełnie wyjątkowych wypadkach. W dalszej konsekwencji tego zabrania się bezwarunkowo łączenia dwóch uposażeń normalnych (etatowych) ze Skarbu Państwa przy piastowaniu dwóch odrębnych posad państwowych"16. Poza tym, „postanowiono powołać do życia Naczelną Radę Sanitarną, złożoną z szefów sanitarnych wszystkich ministerstw i władz centralnych, posiadających agendy sanitarne pod przewodnictwem Ministra Zdrowia Publicznego. Zadaniem Rady będzie skoordynowanie i zcentralizowanie całej akcji zwalczania chorób zakaźnych", przyjęto także projekt ministra rolnictwa „W sprawie utworzenia Urzędu Zagospodarowania Odłogów”, omawiano kwestię walki z lichwą, „z zaznaczeniem, że handel artykułami codziennej potrzeby mogą wykonywać wyłącznie osoby wykazujące się opłaconym patentem, względnie posiadaną kartą przemysłową", zadecydowano o likwidacji resortu zdrowia, który miał zostać włączony do MSW jako „urząd Zdrowia Publicznego z ciałem doradczym tzw. Radą Sanitarną oprócz agend, dotyczących opieki społecznej oraz agend mieszkaniowych, które przejdą do Ministerstwa Pracy

15 Ibidem, p. 32, 33.

16 Uzasadnieniem wprowadzenia tych przepisów było uznanie, że „znaczne podniesienie uposażeń urzędników i funkcjonariuszy państwowych nakłada na Skarb Państwa nadmierny ciężar, który musi być zrównoważony uproszczeniem administracji, wzmożoną wydajnością pracy, należytym wykorzystaniem sił i złączoną z tym bezwzględną ich redukcją, co odpowiada rezolucji sejmowej z dnia 28 lipca 1919 r.", ibidem, p. 66. 
i Opieki Społecznej”, przyjęto także „wniosek nagły p. Ministra Robót Publicznych $\mathrm{w}$ sprawie opracowania projektu budowy portu morskiego na lewym brzegu Wisły, na terytorium województwa pomorskiego" ${ }^{\prime 17}$.

Na lutowych posiedzeniach gabinetu $(3,5,9,12,16,19,23$ i 25 lutego - wszystkim przewodniczył premier) rozpatrywano: sprawę „wniosku sejmowego o zburzeniu Soboru i dzwonnicy na placu Saskim", z czym rząd zgodził się tylko w sprawie zburzenia samej dzwonnicy, $\mathrm{z}$ "pozostawieniem natomiast Soboru" (który ostatecznie został również zburzony), sprawy trudności z aprowizacją (z tego powodu premier poruszył „sprawę wysłania do Południowej Ameryki specjalnych pełnomocników celem poczynienia tam znaczących zakupów środków żywnościowych"), „przyjęto projekt ustawy o przedsiębiorstwach, trudniących się czynnościami bankierskimi" oraz "projekt ustawy w przedmiocie przenoszenia prawa własności nieruchomości na obcokrajowców", zatwierdzano wnioski do Naczelnika Państwa o nominacje urzędnicze, mimo wojennej atmosfery nie przyjęto projektu ustawy o powołaniu rocznika 1902 do służby wojskowej; "podjęcie tego projektu ponownie po pewnym czasie uzależniono od dalszego rozwoju wypadków politycznych”, , przyjęto wniosek Min. W. R. i O. P. w sprawie przyznania mu dodatkowego kredytu na zasiłki dla szkół prywatnych”, „w poruszonej przez p. Ministra Zdrowia sprawie masowego wywozu lekarstw zagranicę przez cudzoziemców, korzystających z prawa eksterytorialności, uznano, że wdrożenie odpowiednich środków zapobiegawczych winno być przekazane do omówienia Komitetowi Ekonomicznemu Ministrów", omawiano także sprawy wydawania zaległych deputatów dla urzędników, "przyjęto wniosek Min. W. R. i O. P. w sprawie oddania na użytek Uniwersytetu Jana Kazimierza we Lwowie gmachu b. Sejmu i Wydziału Krajowego" i "przyjęto projekt ustawy o utworzeniu Urzędu Sztuk Pięknych"18.

W sprawach polityki zagranicznej doszło $\mathrm{w}$ tym czasie do pewnego przesilenia; 6 lutego, na posiedzeniu połączonych komisji sejmowych: wojskowej i spraw zagranicznych, $\mathrm{w}$ obecności premiera i kilku ministrów - rosyjskie propozycje "pokojowe” zostały odrzucone. Należy to uznać za całkowicie uzasadnione, biorąc pod uwagę, że polski wywiad wojskowy donosił, już na początku

17 Ibidem, p. 98, 99, 141.

18 W związku „z poruszoną sprawą wydatków reprezentacyjnych poszczególnych pp. Ministrów, uznano, że tworzenie dla nich osobnych funduszów dyspozycyjnych lub reprezentacyjnych nie jest wskazane natenczas”. Debatowano także „nad uprawnieniami Prezydenta Rzeczypospolitej w dziedzinie naczelnego dowództwa nad armią" (w redagowanym projekcie przyszłej konstytucji) i „postanowiono zaproponować Komisji Konstytucyjnej ze strony Rządu [...] że Prezydent Rzeczypospolitej jest zwierzchnim naczelnikiem wszystkich sił zbrojnych Rzeczypospolitej. [...] Na wypadek wojny mianowany jest na wniosek Rady Ministrów przez Prezydenta Rzeczypospolitej naczelny wódz armii, który zarazem jest Ministrem Spraw Wojskowych, odpowiedzialnym przed Sejmem”. Zdarzało się, że przyjmowano również tak „ważne” wnioski, jak „Min. Skarbu w sprawie umundurowania woźnych i gońców"..., ibidem, p. 182, 196, 223, 300, 301, 312, 336, 337. 
1920 roku, o znacznym przyśpieszeniu zbrojeń Armii Czerwonej ${ }^{19}$. Wprawdzie Stanisław Grabski zdecydowanie wypowiedział się za kontynuowaniem (przerwanych w grudniu 1919 roku) pertraktacji z delegacją rosyjską; w opozycji do eskalacji konfliktu z Moskwą trwali również ludowcy z „Piasta”, a nawet (wydawałoby się „piłsudczykowska”) Polska Partia Socjalistyczna, lecz ostatecznie żadna z partii "sejmowych” nie zgłosiła votum nieufności wobec premiera rządu. W wielu miastach kraju organizowano (głównie przez komunistów) manifestacje antywojenne, co często opisywała prasa ${ }^{20}$.

19 Dostrzegano to także na Zachodzie; w brytyjskim parlamencie minister wojny Winston Churchill informował, że siły bolszewickie, w ciągu jednego zimowego miesiąca, wzrosły o 60 tysięcy żołnierzy, co uznawał za przyspieszone przygotowania ofensywne wobec Polski. W styczniu 1920 r. Armia Czerwona dysponowała przeciwko Polsce zaledwie czterema dywizjami; w połowie kwietnia już dwudziestoma dywizjami piechoty i trzema dywizjami kawalerii, a w głębi Rosji koncentrowano kolejne dywizje piechoty i ściągano I Armię Konną z frontu południowego, która rozbiła już wojska Antona Denikina. Strona polska dysponowała tylko osiemnastoma dywizjami, niejednolicie zresztą uzbrojonymi, a poza tym istniały duże trudności z rozbudową formacji wojskowych z powodu braku odpowiedniego wyposażenia, a nawet umundurowania. Churchill należał do bardzo nielicznych, znanych na zachodzie polityków, którzy zrozumieli, że świat ma przed sobą nowy rodzaj systemu sprawowania władzy, obojętnego na jakiekolwiek normy prawne, obyczaje czy honor. W kwietniu 1919 r. przerażająco trafnie stwierdził: „Ze wszystkich tyranii w historii bolszewicka jest najgorsza, najbardziej niszczycielska, najbardziej poniżająca", cyt. za: P. Johnson, Historia Świata (od 1917 r.), Londyn 1989, s. 82; R. Conquest, Lenin. Prawda o wodzu rewolucji, Warszawa 1993, s. 114 i nast.; idem, Stalin, Warszawa 2000, s. 102; B. Wiliams, Lenin, Wrocław 2002, s. 121; R. Stobiecki, Bolszewizm a historia: próba rekonstrukcji bolszewickiej filozofii dziejów, Łódź 1998, s. 127-140; J. Goclon, W obronie Europy..., s. 57-62; zob. A. Pepłoński, Wywiad w wojnie polsko-bolszewickiej 1919-1920, Warszawa 1999, s. 37 i in.; Polski wywiad wojskowy, red. P. Kołakowski, A. Pepłoński, Toruń 2006, s. 86 i in.; J. Smaga, Rosja w 20 stuleciu, Kraków 2001, s. 48 i in.; E. H. Carr, The Bolshevik Revolution, Londyn 1966, s. 16 i in.; K. Srokowski, Na czerwonym Olimpie, Lwów 1934, s. 36 i in.; idem, Elita bolszewicka. Studium socjologiczne, Kraków 1927, s. 14 i nast.

20 W tym czasie władcy Kremla rozpoczęli podstępną agitację skierowaną do robotników krajów zachodnich Europy (później także Azji), wzywając ich, aby zatrzymywali transporty kolejowe i morskie z amunicją, bronią, a nawet żywnością dla Polski, co niestety okazywało się często skuteczne i wynikało z bardzo słabej znajomości okrutnych realiów panujących w ówczesnej Rosji, a jednocześnie z naiwnej wiary w marksistowskie „świetlane hasła”, które tak masowo rozgłaszali zachodni, komunistyczni agitatorzy, m.in. inicjując w Londynie pochody z hasłami "ręce precz od Kraju Rad”, J. Goclon, W obronie Europy..., s. 100-102; M. Wrzosek, Wojny o granice Polski Odrodzonej: 1918-1920, Warszawa 1992, s. 101; A. Ciołkosz, Koniec monolitu, Londyn 1964, s. 4; I. Babel, Dziennik 1920, Warszawa 1990, s. 7; T. Żenczykowski, op. cit., s. 27, 28; D. Wołkogonow, Lenin, prorok raju, apostoł piekła, Warszawa 2006, s. 24, 74, 353, 357, 372, 380; W. I. Lenin, Co to jest internacjonalizm?, Warszawa 1982, s. 212; J. Kumaniecki, Dwa oblicza dyplomacji radzieckiej. Rokowania w Mińsku i Rydze, [w:] Wojna polsko-sowiecka 1920 roku. Przebieg walk i tło międzynarodowe, Warszawa 1991, s. 23, 24; N. Davies, op. cit., s. 115-117, 178, 179; E. V. D’Abernon, Osiemnasta decydujaca bitwa w dziejach świata pod Warszawa 1920 roku, Warszawa 1990, s. 55, 56; por. A. Leinwald, Ruch w obronie Rosji Radzieckiej podczas wojny polsko-radzieckiej 1920 r., „Biuletyn Akademii Wojskowo-Politycznej im. F. Dzierżyńskiego" 1957, nr 1; L. J. Mac Farlane, Hands off Russia, „Past and Present” 1967, s. 18 i nast.; zob. Z. G. Kowalski, Wojna polsko-bolszewicka na łamach polskich fachowych periodyków wojskowych z lat 1919-1939, Torun 2002, s. 27 i in.; A. Paczkowski, Prasa polska w latach 1918-1939, Warszawa 1980, s. 56 i in.; K. Paduszek, Działalność propagandowa służb informacyjno-wywiadowczych Wojska Polskiego w czasie wojny polsko-bolszewickiej 1919-1921, Toruń 2004, s. 79 i nast. 
Pomimo narastającego napięcia na marcowych posiedzeniach rządu $(1,8$, 10, 11, 14, 18, 20, 22, 24 i 29 marca - wszystkim przewodniczył premier) nadal omawiano głównie sprawy krajowe, w tym: projekt „ustawy o ludowych szkołach rolniczych męskich i żeńskich”, „niebezpieczny stan ruchu strajkowego w Zagłębiu węglowym Dąbrowskim", nominacje urzędnicze, sprawę „przyznania nadzwyczajnego dodatku drożyźnianego urzędnikom i funkcjonariuszom państwowym”, ,projekt ustawy o przywróceniu praw majątkowych unitom”, sprawy "kontroli państwowej” w przyszłej konstytucji, sprawy podniesienia podatków, „projekt ustawy o organizacji Urzędów Ziemskich”, nominacje urzędnicze w ministerstwach, „projekt statutu Związku Lekarzy Rządowych w Państwie Polskim", uchwałę rządu o wprowadzeniu tzw. soboty angielskiej („w okresie letnim, tj. od dnia 1 kwietnia do dnia 30 września, czas urzędowania $\mathrm{w}$ soboty we wszystkich urzędach państwowych trwa zamiast siedmiu, pięć godzin") ${ }^{21}$.

Kwiecień był miesiącem intensywnych przygotowań do wyprawy na Kijów, a na posiedzeniach gabinetu (prawie wszystkie pod przewodnictwem premiera) w dniach: 1, 8, 12, 15, 19, 22 (na tym posiedzeniu początkowo przewodniczył S. Wojciechowski, potem przejął to premier) i 29 kwietnia omawiano: utworzenie Urzędu Emigracyjnego (w miejsce likwidowanego „Państwowego Urzędu do spraw powrotu Jeńców, Uchodźców i Robotników"), wniosek MSZ „W sprawie przystąpienia Polski do Międzynarodowego Urzędu Hygieny Publicznej”, wniosek MSZ „w sprawie wydania rozporządzenia Rady Ministrów w przedmiocie tymczasowego uregulowania ruchu tranzytowego i sąsiedzkiego między Polską a Niemcami"; upoważniono Ministerstwo Rolnictwa "do bezzwłocznego zakupu w porozumieniu z Najwyższą Izbą Kontroli Państwa dóbr Jaworzyna ks. Hohenlohego na Spiszu", zastrzegając na razie „zupełną poufność dla tej transakcji”; zdziwienie może wzbudzić, że „W sprawie przedstawionego przez Prezydium Rady Ministrów projektu ustawy orderu Orła Białego Rada Ministrów uznała ustanowienie takiego orderu dla obywateli Państwa Polskiego za niepotrzebne", ale nie można zapominać, że to najstarsze polskie odznaczenie (ustanowione w 1705 roku przez Augusta II Mocnego) zostało po upadku powstania listopadowego włączone do rosyjskich orderów; trudno powiedzieć, co zadecydowało o takiej decyzji gabinetu, ponieważ w stenogramie posiedzeń nie ma żadnego wyjaśnienia (zresztą order ten

21 Na jednym z marcowych posiedzeń (24.03) „na wniosek p. Ministra Wojciechowskiego polecono Min. Spraw Wojskowych udzielenie jeszcze przed świętami wielkanocnymi jeńcom ukraińskim, znajdującym się w obozach, w możliwie szerokich rozmiarach bezterminowych urlopów, które przeciągnęłyby się aż do czasu, gdy będzie można zastosować do nich ogólną amnestię. Zarazem zwrócono Min. Spraw Wojskowych uwagę na potrzebę starannego odwszenia tych jeńców przed wypuszczeniem ich na wolność, by zapobiec rozszerzeniu przez nich epidemii" - co jest jednak dowodem, że w polskich obozach panowały bardzo trudne warunki bytowe, AAN, PRM, mf. 20053, p. 362, 396, 417, 468, 500, 547, 548, 581, 582. 
został i tak przywrócony w późniejszym czasie); dalej rozpatrywano nominacje „starszych radców i radców Prokuratorii Generalnej”, a na wniosek premiera „uchwalono przyznać p. Marianowi Dubieckiemu, ostatniemu żyjącemu członkowi Rządu narodowego z roku 1863 dożywotnią dotację ze Skarbu Państwa"22.

Na kwietniowych posiedzeniach gabinetu - mimo przyspieszonych przygotowań militarnych w armii - prawie wcale nie poruszano kwestii wojny, omawiając jedynie: sprawy urzędnicze, dodatki drożyźniane, pożyczki państwowe, uposażenie urzędników i kolejarzy, czy poprawki do „ustawy z 13 lutego 1920 r., dotyczącej zwolnienia podań o udzielenie pożyczek z kredytu jednego miliarda marek, przyznanego na zagospodarowanie odłogów, od wszelkich opłat stemplowych i innych" oraz projekty m.in. ustaw: „o biletach skarbowych", „w przedmiocie papierów mających bezpieczeństwo pupilarne”, „w przedmiocie przyjmowania obligacji wojennych pożyczek austriacko-węgierskich przy subskrypcji wewnętrznej długoterminowej pożyczki państwowej z r. 1920”, czy „w przedmiocie przyznania bonifikacji posiadaczom asygnat 5\% wewnętrznej pożyczki państwowej z r. 1918”. Jedynym projektem do momentu rozpoczęcia wyprawy kijowskiej był „wniesiony przez Pana Ministra Spraw Wojskowych w trybie nagłym, poza porządkiem dziennym, projekt ustawy w przedmiocie przedłużenia mocy obowiązującej ustawy z dnia 6 kwietnia 1919 r. o dostarczaniu mieszkań na potrzeby wojska" (19 kwietnia - przyjęty przez rząd) ${ }^{23}$.

Pierwsza połowa kwietnia to już okres gorączkowych przygotowań do uderzenia na Ukrainę. Do sztabu generalnego Wojska Polskiego nadal napływały doniesienia polskiego wywiadu o rosyjskich planach operacyjnych i narastającej koncentracji wojsk bolszewickich. Czas działał przeciwko Polsce i z każdym dniem przechylał szalę zwycięstwa na stronę Armii Czerwonej24.

22 AAN, PRM, mf. 20054, t. 10, p. 1, 2, 35.

23 Na posiedzeniu w dniu 22 kwietnia, a więc na trzy dni przed rozpoczęciem wyprawy kijowskiej, minister robót publicznych wniósł zaskakującą „w formie wniosku nagłego sprawę opróżnienia przez władze wojskowe w Zamościu, budynku na pomieszczenie internatu”, co „przekazano Ministrowi Robót Publicznych do załatwienia w porozumieniu z Ministrem Spraw Wojskowych"; na ostatnim kwietniowym posiedzeniu „przyjęto bez zmian [...] projekt ustawy w przedmiocie zmiany niektórych postanowień ustawy z dnia 7 kwietnia 1919 r. w sprawie powołania dyplomowanych lekarzy do służby czynnej wojskowej", ibidem, p. 81, 115, 223.

24 Szczegółowy plan uderzenia na Polskę opracował (w lutym 1920 r.) pułkownik Borys Szaposznikow (były carski sztabowiec), który przewidywał rosyjską ofensywę - siłami czterech armii przez tereny Białorusi. Dowództwo polskie liczyło się z zakończeniem koncentracji wojsk bolszewickich w maju, lecz już na początku kwietnia zaczęły napływać alarmujące informacje polskiego wywiadu o znacznym przyspieszeniu mobilizacji. Poza tym każdego dnia polepszało się uzbrojenie Armii Czerwonej w wyniku przejmowania angielskiego i francuskiego sprzętu wojskowego, porzucanego przez rozbite rosyjskie „białe armie”. O przygotowywanym uderzeniu na Polskę uprzedzał Piłsudskiego król Hiszpanii Alfons XIII, J. Goclon, W obronie Europy..., s. 62-64; S. Jaczyński, Generalicja obu walczących stron. Próba charakterystyki i oceny, [w:] Rok 1920. Z perspektywy osiemdziesięciolecia, Warszawa 2001, s. 31; W. J. Spahr, Generałowie Stalina, Warszawa 2001, s. 107; 
Jednak nawet $\mathrm{w}$ takiej sytuacji polski minister spraw zagranicznych S. Patek, w porozumieniu z Naczelnym Wodzem, zaproponował stronie rosyjskiej wznowienie (10 kwietnia) rokowań pokojowych w miejscowości Borysów, położonej w centrum frontu białoruskiego (miejsce negocjacji i cały okręg obejmowałoby zawieszenie broni). Przyjęcie polskiej propozycji utrudniłoby zakończenie koncentracji III, IV, XV i XVI rosyjskich armii i dalsze działania wojenne, a z drugiej strony wytrącałoby stronie przeciwnej dotychczasowy argument, że Polacy unikają pertraktacji. Warunki pokoju - ustalone między Naczelnikiem Państwa a premierem L. Skulskim - zawierały: Rosja uzna prawa Polski do ziem w granicach sprzed 1772 roku, a władze polskie zadecydują, w porozumieniu z ludnością zamieszkałą na tym terytorium, co do ich dalszej przynależności państwowej. Piłsudski (i popierający jego cele rząd L. Skulskiego) stał na stanowisku uzyskania niepodległości dla Ukrainy i Litwy (choć Wilno miało pozostać przy Polsce), a okręg białoruskiego Mińska miał otrzymać samorząd terytorialny. Dla Lenina takie „warunki” były nie do przyjęcia. Tym samym przygotowania wojenne wkroczyły w ostatnią fazę, a większość posłów ostatecznie zaakceptowała politykę „wschodnią" Naczelnego Wodza ${ }^{25}$.

Jedynym sojusznikiem, na którego Polacy mogli wówczas liczyć, byli praktycznie tylko Ukraińcy, dlatego władze polskie uznały formalnie, 21 kwietnia 1920 roku, Dyrektoriat Ukraińskiej Republiki Ludowej. Po kilku dniach podpisano również konwencję wojskową z atamanem Semenem Petlurą, naczelnym wodzem wojsk ukraińskich (faktycznym przywódcą Ukraińskiej Republiki Ludowej) $)^{26}$.

A. Albert (W. Roszkowski), Najnowsza Historia Polski, cz. 1, 1918-1939, Warszawa 1983 (II obieg), s. 49; S. Cat-Mackiewicz, Historia Polski, cz. 1, Wrocław 1989 (II obieg), s. 46; A. Pragier, Czas przeszły dokonany, Londyn 1966, s. 201; zob. B. Szaposznikow, Warszawskaja operacja, Moskwa 1933, s. 11 i in.; P. Zaremba, op. cit., t. 1, s. 163-165.

Przywódca bolszewików Włodzimierz Lenin na IX zjeździe rosyjskiej partii komunistycznej (29 marca 1920 r.) ujawnił fakt znaczącego zwiększania rosyjskiego potencjału wojennego i jego cel - mówiąc: „Wiemy, że każdy miesiąc przynosi nam gigantyczny wzrost sił, które nie przestaną rosnąć. Mamy przed sobą formalną propozycję pokojową przedstawioną przez Polaków. Musimy sobie stanowczo powiedzieć, że bez względu na propozycje pokojowe nie odrzucamy możliwości wojny"; na co - znając sytuację w polskim wojsku - mógł już sobie pozwolić. Zresztą polskie warunki pokojowe, uchwalone przez sejmową komisję spraw zagranicznych w porozumieniu z polskim rządem, były dla „wodza rewolucji" nie do przyjęcia; odrzucał przede wszystkim polskie żądanie, aby wyłącznie naród ukraiński, w wolnych i powszechnych wyborach zadecydował, czy na Ukrainie ma istnieć bolszewicka Ukraińska Republika Rad, z całkowicie zależnym od Rosji „rządem” Chrystiana Rakowskiego (właśc. Kristu Stanczew) w Kijowie, czy Dyrektoriat Ukraińskiej Republiki Ludowej, cyt. za: P. Zaremba, op. cit., s. 164; Czarna księga komunizmu. Zbrodnie, terror, prześladowania, Warszawa 1999, s. 689; J. Cygan, W. J. Wysocki, Niepodległość była nagrodą: polski wysitek zbrojny w latach 1914-1921, Warszawa 1999, s. 97, 101; B. Skaradziński, Polskie lata 1919-1920, t. 2, Warszawa 1993, s. 18; W. Pronobis, Polska i świat w XX wieku, Warszawa 1991, s. 62 i nast.; A. Wątor, op. cit., s. 58.

26 Sytuacja S. Petlury była trudna z powodu braku formalnego uznania władz Ukraińskiej Republiki Ludowej przez mocarstwa zachodnie i sojusz z rządem w Warszawie był dla niego praktycz- 
Na majowych posiedzeniach $(1,5,6,10,13,17,20,25,27$ i 31 maja - wszystkie pod przewodnictwem premiera) - a więc odbywających się już po rozpoczęciu działań wojennych, rząd rozpatrywał nadal niemal wyłącznie sprawy „cywilne"; do najważniejszych należało: omawianie projektów ustaw - „o organizacji władz naczelnych", "o uposażeniu urzędników”, "o uposażeniu sędziów i prokuratorów", "o wynagrodzeniu nauczycieli publicznych szkół ludowych" i "nauczycieli i dyrektorów państwowych szkół średnich ogólnokształcących i seminariów nauczycielskich”, i odpowiednio „szkół zawodowych", „o wynagrodzeniu profesorów, docentów i pomocniczych sił naukowych w państwowych szkołach akademickich", "o uposażeniu pracowników kolei państwowych", „o opłatach stemplowych od weksli"; nominacje sędziowskie i urzędnicze, "projekt ustawy aprowizacyjnej na rok 1920/21", "projekt ustawy w przedmiocie kredytu dla Skarbu Państwa w Polskiej Krajowej Kasie Pożyczkowej”, „o ubezpieczeniach państwowych i o państwowej dyrekcji ubezpieczeń", projekt statutu "Związku lekarzy rządowych w Państwie Polskim", ,projekt ustawy tymczasowej o źródłach dochodowych gmin wiejskich" (na terenie b. zaboru rosyjskiego) oraz "projekt ustawy o komunalnych kasach oszczędności" i „projekt ustawy o ustroju szkół akademickich" ${ }^{27}$.

W czerwcu odbyły się już tylko trzy posiedzenia tego gabinetu (5, 7 i 10 czerwca; pierwsze i trzecie - pod przewodnictwem premiera; drugiemu przewodniczył minister aprowizacji S. Śliwiński), na których omawiano: „projekt ustawy w przedmiocie przyznania Państwu prawa przedsięwzięcia środków dla powiększenia zapasu ziemi na parcelację i osadnictwo" (na ostatnim posiedzeniu rządu, w dniu 10 czerwca, projekt ten „zdjęto z porządku dziennego z uwagi na dymisję gabinetu"), "przyjęto projekt ustawy o powołaniu b. podoficerów urodzonych w latach 1895 do 1890 włącznie do wojska”, "polecono Ministrowi Spraw Wojskowych i Sprawiedliwości przystąpić niezwłocznie do rewizji zasad organizacji sądownictwa wojskowego w celu doprowadzenia go na poziom społecznego systemu wymiaru sprawiedliwości”, "przyjęto pro-

nie jedynym, racjonalnym rozwiązaniem. Tekst traktatu polsko-ukraińskiego podaje N. Davies, op. cit., s. 101, 102; J. Goclon, W obronie Europy..., s. 68, 69; zob. też: M. Klimecki, Wojna czy pokój? Polsko-ukraińskie negocjacje 1918-1921, [w:] Polska i Ukraina: sojusz 1920 roku i jego następstwa, red. W. Rezner, E. Wiszka, Z. Karpus, Torun 1997; R. Galuba, Pertraktacje polityczno-wojskowe między Polska a Ukraińska Republiką Ludowa (lipiec - sierpień 1919 roku), „Mars” 1994, t. 2, s. 53-68; S. Benedykt, Kijowskie "poprawki historyczne", "Zeszyty Historyczne” (cyt. dalej: ZH), Paryż 1975, s. 31; A. Deruga, Początek rokowań o sojusz między Pitsudskim a Petlurą (styczeń - lipiec 1919), t. VI: Z dziejów stosunków polsko-radzieckich, 1970; P. Wandycz, Z zagadnień wspótpracy polsko-ukraińskiej w latach 1919-1920, ZH, nr 12, Paryż 1967; idem, Nieznane listy Petlury do J. Piłsudskiego, ZH, nr 8, Paryż 1965.

27 Na jednym z majowych posiedzeń omawiano wnioski zgłoszone do parlamentarnej komisji konstytucyjnej i rząd uznał „za bezsporną tylko tezę objętą postanowieniem art. $12 \mathrm{z}$ wniosku księdza Lutosławskiego", że "każdy obywatel ma prawo do opieki państwa nad jego pracą a także w razie braku pracy, choroby, wypadku i niedołęstwa - drogą ubezpieczenia społecznego i ustawodawstwa ochrony pracy", AAN, PRM, mf. 20053, p. 243-246, 475, 496, 497, 517, 558. 
jekt ustawy o utworzeniu urzędu Nadzwyczajnego Komisarza Naczelnego do walki z epidemiami", przyjęto także "projekt ustawy o organizacji konsulatów i o czynnościach konsulów" i zakończono ostatnie czytanie projektu ustawy „o zakresie działania władz najwyższych” oraz „przyjęto projekt zmian ustawy o ordynacji wyborczej" 28 .

Analiza wszystkich protokołów posiedzeń rządu Leopolda Skulskiego ukazuje, że gabinet ten praktycznie wcale nie uczestniczył w przygotowaniach do wyprawy kijowskiej i tym samym wszystko w tym zakresie toczyło się poza Radą Ministrów, w samym Ministerstwie Spraw Wojskowych i Sztabie Generalnym, a rozstrzygające decyzje zapadały w pałacu Belwederskim - o czym decydował Naczelny Wódz.

Należy podkreślić, że podstawowym celem „wyprawy kijowskiej” dla Piłsudskiego było stworzenie narodowi ukraińskiemu możliwości wybrania swoich władz, w wolnych, powszechnych wyborach, przeprowadzonych na całej Ukrainie, których wynik uszanować miałaby zarówno Polska, jak i Rosja; uszanować także $\mathrm{w}$ przypadku, gdyby $\mathrm{w}$ tych wyborach Ukraińcy zaakceptowali (co było mało prawdopodobne) „rząd” Chrystiana Rakowskiego, narzucony przez Lenina w Kijowie, czy jakąkolwiek inną formę związku państwowego z Rosją 29 . Naczelny Wódz Józef Piłsudski, po zakończeniu zwycięskiej operacji militarnej, pragnął doprowadzić do współpracy gospodarczej i ewentualnego przymierza wojskowego obydwu suwerennych państw - Polski i Ukrainy. Komendant był realistą, rozumiał zarówno aspiracje niepodległościowe narodu ukraińskiego, jak i głębokie antagonizmy, zarówno te historyczne, jak i te najnowsze (powstałe w wyniku ostatnich walk o Galicję i Lwów), aby rozważać nierealne koncepcje federacyjne z tym państwem (w literaturze można często spotkać się z poglądem, że Ukraina również miała być częścią federacji - co nie jest prawdą!). Jednocześnie zdawał sobie sprawę, że tylko stworzenie silnej Rzeczypospolitej w związku federacyjnym z Białorusią i Litwą oraz powołanie niezależnej od Rosji Ukrainy, związanej sojuszem militarnym z Polską, może stworzyć gwarancje bezpieczeństwa dla polskiego

28 Mimo zbliżającego się niebezpieczeństwa ze strony Armii Czerwonej rząd zajmował się również sprawami takiej „rangi”, jak przyjęcie projektu "ustawy o taksie dla komorników sądowych”, czy projektu „ustawy o zakazie wywozu za granicę kruszców szlachetnych”, ibidem, p. 593, 599, 616, $617,636,649$.

29 Funkcję ukraińskiego „premiera” pełnił (faktycznie podporządkowany atamanowi S. Petlurze) Iwan Mazepa, rezydujący (do czasu polskiej wyprawy na Ukrainę) w Chmielniku, J. Goclon, W obronie Europy..., s. 69, 70. Zwięzłą syntezę ówczesnych, politycznych relacji polsko-ukraińskich przedstawił E. Prus, Hulajpole. Burzliwe dzieje kresów ukrainnych (od stowiańskiego świtu do Cudu nad Wisła), Wrocław 2003, s. 384-414; S. Szajdak, Polsko-Ukraiński sojusz polityczno-wojskowy w 1920 roku, Warszawa 2005, s. 91 i nast.; M. Kuczerepa, Układ Warszawski z 1920 roku: geneza, problemy, następstwa, [w:] Rok 1920. Z perspektywy osiemdziesięciolecia, Warszawa 2001, s. 204-215; R. Torzecki, Kwestia ukraińska w Polsce w l. 1923-1929, Kraków 1989, s. 8; zob. B. Miedziński, Polityka wschodnia Piłsudskiego, ZH, nr 32, Paryż 1975; A. Ostoja-Owsiany, Rok 1920 w krzywym zwierciadle propagandy i w rzeczywistości, Warszawa 1981 (II obieg), s. 22. 
narodu. W zamierzeniach Naczelnego Wodza federacja ta miała stanowić „mocarstwo", z którym - w tej części Europy - musiano by się liczyć.

Prezes Rady Ministrów L. Skulski zasadniczo podzielał te poglądy, ale rząd działał jednak w cieniu przygotowań wojennych. Do ważniejszych wystąpień członków gabinetu w tym czasie należało exposé ministra skarbu, W. Grabskiego, wygłoszone w Sejmie 27 lutego 1920 roku, w którym przedstawił sposoby, jakimi zamierzał zrównać wydatki z dochodami; dotychczasowe podatki oraz nowe - przeznaczał na pokrycie „zwyczajnych” wydatków kraju, natomiast pokrycie wszelkich wydatków „nadzwyczajnych”, głównie związanych ze zbliżającą się wojną, zamierzał uzyskać poprzez rozpisanie wewnętrznej pożyczki (oczekując wpływów w wysokości około 1 mld marek) 30. Ostateczny projekt budżetu minister W. Grabski przedłożył 24 kwietnia, ustalając wydatki na 47 mld marek, choć w roku poprzednim wyniosły 15 mld. Największą część stanowiły oczywiście prognozowane koszty przygotowań wojennych, pozostałe miały wynikać z podniesienia płac ${ }^{31}$, aprowizacji kraju, ale też ze spadku wartości marki polskiej. Jednocześnie zapowiedział dodatkową emisję w wysokości 5 mld marek (czyli zwykły dodruk banknotów, co jedynie zwiększało inflację); praktycznie było to jedyne pewne źródło przychodów dla pokrycia wydatków wojennych... Należy dodać, że organizowanie reglamentacji wywoływało liczne protesty, mimo że dotyczyło stosunkowo wąskiej grupy ludności. Strajki (wprawdzie nieliczne) podejmowali pracownicy zakładów o dużym znaczeniu gospodarczym (górnictwo, elektrownie) ${ }^{32}$. Następnego dnia, po rozpoczęciu wyprawy kijowskiej, doszło w Poznaniu (26 kwietnia) do krwawych zamieszek, w których zginęło siedmiu demonstrantów w czasie strajku kolejarzy ${ }^{33}$. Należy pamiętać, że gabinet L. Skulskiego miał stosunkowo niewielkie pole manewru; wydatki związane z rozpoczętą wojną sięgały $60 \%$ całego bu-

30 Problem aprowizacji, w tym zaopatrzenie wsi w odpowiednie ilości nawozów sztucznych, usiłowano rozwiązać poprzez eksport cukru i krochmalu do Anglii, AAN, PRM, mf. 20053, t. 9, p. 2. Grabski planował ponadto dokonanie reformy walutowej przez utworzenie Banku Emisyjnego i oparcie nowej waluty (,złotego") na eksporcie drewna i amerykańskiej pożyczce, J. Goclon, Rząd Leopolda Skulskiego..., s. 192-195; A. Wątor, op. cit., s. 58.

31 Rząd, decydując się na podwyżki płac, podjął jednocześnie uchwałę, iż „znaczne podniesienie uposażeń urzędników i funkcjonariuszy państwowych nakłada na Skarb Państwa nadmierny ciężar, który musi być zrównoważony uproszczeniem administracji, wzmożoną wydajnością pracy, należytym wykorzystaniem sił i złączoną z tym bezwzględną ich redukcją", A. Wątor, op. cit., p. 66.

32 AAN, PRM, mf. 20052, t. 8, p. 570; mf. 20053, t. 9, p. 64; mf. 20054, t. 10, p. 518, 690. Za sukces ministra W. Grabskiego można uznać unifikację waluty na ziemiach b. Kongresówki i Galicji, w czym udało mu się przeforsować (15 stycznia 1920 r.) korzystną dla skarbu państwa wymianę w relacji 70:100, mimo ostrych protestów posłów galicyjskich, A. Wątor, op. cit., s. 59; A. Paczkowski, Leopold Skulski..., s. 118.

33 Strajki kolejarzy zaczęły się już na początku stycznia 1920 r. we Lwowie, a w tym samym miesiącu Rada Ministrów odrzuciła „wniosek p. Ministra b. Dzielnicy Pruskiej, aby dla podniesienia sprawności kolei stworzyć centralne urzędy dla całej Polski pod kierownictwem Min. Kolei Żelaznych". Przez takie posunięcia rząd w żadnym przypadku nie mógł liczyć na akceptację swojej polityki 
dżetu państwa! Wprawdzie pobór do wojska (początkowo dwóch roczników) zmniejszył nieco bezrobocie, a zamówienia wojskowe wpłynęły korzystnie na koniunkturę $\mathrm{w}$ przemyśle i rolnictwie - to jednak potrzeby armii pochłaniały większą część produkcji, co tylko zwiększało niedobory rynku (poważnie obciążało to także bilans zagraniczny kraju). Wspomniana pożyczka państwowa (przymusowa!) oraz zaostrzenie reglamentacji handlu zagranicznego - wywoływały opory wielu przedsiębiorców ${ }^{34}$.

Należy jednak podkreślić, że rząd L. Skulskiego próbował - mimo rozpoczętej kampanii wojennej - doprowadzić do pewnej unifikacji gospodarczej państwa; 1 kwietnia wprowadzono jednolity system skarbowy i podatek dochodowy, a 29 kwietnia unifikację waluty. Rozpoczęto prace legislacyjne nad ustawą o szkolnictwie wyższym, jednocześnie po raz pierwszy rozpatrując koncepcję zbudowania portu na polskim wybrzeżu Bałtyku. 1 czerwca została wprowadzona jednolita taryfa kolejowa dla całego państwa. Przygotowano także projekt ustawy o naczelnych władzach administracyjnych. W okresie funkcjonowania tego gabinetu Sejm uchwalił 8-godzinny dzień pracy i 46-godzinny tydzień pracy (i to już 18 grudnia 1919 roku) oraz powszechny system ubezpieczeń społecznych (19 maja 1920 roku) ${ }^{35}$.

Jednak zagrożenie upadkiem tego gabinetu zaczęło pojawiać się jeszcze przed rozpoczęciem „wyprawy na Kijów”; podstawą niezgody okazała się sprawa reformy rolnej, której rząd L. Skulskiego po prostu nie realizował, mimo że Sejm uchwalił (13 lutego) ustawę dającą możliwość uzyskiwania kredytów na zagospodarowywanie odłogów oraz (18 marca) o możliwości wydzierżawienia gruntów rolnych, obecnie nieużytkowanych. 7 maja (a więc już w trakcie działań wojennych) została uchwalona ustawa o zniesieniu serwitutów na terytorium b. Królestwa „kongresowego”. Jednak najważniejszy był wniosek zgłoszony przez PSL-„Piast” (4 czerwca) w kwestii uchwalenia ustawy o przymusowym wykupie gruntów dla przeprowadzenia parcelacji (w celu wykonania uchwały sejmowej z 10 lipca 1919 roku) ${ }^{36}$. To posunięcie okazało się początkiem końca tego gabinetu, który zaczął tracić poparcie innych partii; najostrzejszą krytykę podnieśli socjaliści (PPS) z powodu znacznego obniżenia poziomu życia społeczeństwa oraz postępującej lawinowo działalności lichwiarskiej, za co w ich pojęciu odpowiedzialność ponosił rząd. Również prawica zarzucała rządowi zbytnią bierność wobec strajków, jakie miały miejsce w niektórych zakładach pracy.

\footnotetext{
w środowisku kolejarzy. Nie można zapominać, że kolej była wówczas najważniejszą formą transportu, co szczególnie $\mathrm{w}$ obliczu przygotowań wojennych powinno mieć priorytetowe znaczenie. Strajki wybuchały również w Zagłębiu Dąbrowskim i w Warszawie, AAN, PRM, mf. 20053, t. 9, p. $1,54,396,438$.

34 Ibidem, mf. 20054, t. 10, p. 141, 405.

35 Ibidem, mf. 20053, t. 9, p. 25, 141; J. Goclon, Rzad Leopolda Skulskiego..., s. 196.

36 J. Goclon, Rząd Leopolda Skulskiego..., s. 197; A. Wątor, op. cit., s. 59.
} 
O tych politycznych sporach niewiele wiedziały szersze kręgi społeczeństwa, ponieważ $\mathrm{w}$ maju nastąpiło zajęcie Kijowa przez Wojsko Polskie, gdzie odbyła się "triumfalna" parada (choć miasto zostało zajęte bez żadnych walk...), którą odebrał gen. Edward Śmigły-Rydz i to wydarzenie przesłoniło zakulisowe tarcia między politykami ${ }^{37}$.

Po wkroczeniu na Ukrainę wojsk polskich i ukraińskich pojawiły się problemy, których Piłsudski nie przewidział; „pochód” polskich dywizji na Kijów nie był przyjmowany przez ukraińską ludność z entuzjazmem. Ukraińscy chłopi obawiali się powrotu polskiego ziemiaństwa do opustoszałych dworów (mimo że Piłsudski zakazał - rzecz mało znana - powrotu polskiemu ziemiaństwu do ich dawnych rezydencji). Zarządowi Cywilnemu Ziem Wschodnich pomagała Straż Kresowa, której działacze z goryczą relacjonowali w raportach, iż "trzeba podkreślić zachowanie się znacznej części miejscowego ziemiaństwa, które swą klasową polityką bardzo często kompromituje sprawę polską" ${ }^{38}$. W opuszczonych przez polskich właścicieli dobrach gospodarzyli już okoliczni chłopi (głównie Ukraińcy), obawiający się utraty tych gospodarstw. Również organizowanie ukraińskich dywizji przebiegało dużo wolniej niż by przypuszczano; doszły do tego problemy z zaopatrzeniem poszczególnych polskich oddziałów. Pojawiły się trudności z zapewnieniem odpowiednich warunków dla formowania ukraińskich dywizji oraz tworzenia niemal od podstaw terenowej administracji ukraińskiej. Naczelną dyrektywą polskiego dowództwa było zapewnienie transportu dla polskich dywizji, które zamierzano przerzucić z Ukrainy na białoruski obszar operacyjny, natychmiast po osiągnięciu celów militarnych na froncie ukraińskim, ale warunkiem realizacji tego planu było utworzenie sześciu dywizji ukraińskich, które wytrwałyby w obronie na linii Dniepru i na przedpolach Odessy. Powodzenie tych założeń zależało z kolei od osiągnięcia celów politycznych, tj. możliwie najszybszego utworzenia administracji ukraińskiej i zjednania sobie miejscowej ludności oraz przekonania jej, że jest to zapowiedź niepodległości, a nie tylko kolejna kampania wojenna (ludność stolicy Ukrainy miała powody do zmęczenia i niewiary w polityczną

37 Polacy byli upojeni sukcesem; Rzeczpospolita nie znała takiego triumfu od czasu „odsieczy wiedeńskiej" króla Jana Sobieskiego w 1683 r. Był to niewątpliwie szczyt popularności Piłsudskiego, którego nie osiągnął nigdy przedtem ani już nigdy potem; nawet wśród politycznych przeciwników pojawiły się propozycje dożywotniej prezydentury, a nawet... korony dla „zwycięskiego wodza" - choć Kijów został faktycznie zajęty bez walki... Tłumy mieszkańców Warszawy witały Naczelnego Wodza jak narodowego bohatera, ale był to triumf pozorny; na Białorusi trwała już rosyjska ofensywa, J. Goclon, W obronie Europy..., s. 86, 87; W. Suleja, op. cit., s. 219; L. Wyszczelski, Kijów 1920, Warszawa 1999, s. 98 i in.; A. Suchcitz, Generałowie wojny polsko-sowieckiej 1919-1920. Mały słownik biograficzny, Białystok 1993, s. 64-65; zob. J. Romer, Sprawa generała Jana Romera, lipiec 1920 - czerwiec 1921, „Niepodległość”, t. 25, Londyn 1992; idem, Pamiętniki, Lwów 1938; J. Skwarczyński, Kampania polsko-ukraińska. Doświadczenia operacyjne i bojowe, Lwów 1921.

38 Cyt. za: N. Davies, op. cit., s. 80; I. Rychlikowa, Ziemiaństwo polskie 1772-1944. Dzieje degradacji klasy, „Dzieje Najnowsze” 1985, R. 17, nr 2, s. 3-21; E. Koko, Polska Partia Socjalistyczna i Józef Piłsudski wobec kwestii ukraińskiej w latach 1918-1920, „Dzieje Najnowsze” 1989, z. 1, s. 5 i nast. 
stabilizację; Kijów przechodził 15 razy z rąk do rąk!). Dopiero po zajęciu Kijowa S. Petlura mógł rozpocząć organizowanie ukraińskiego aparatu państwowego (strona polska zobowiązywała się wyposażyć tworzone dywizje ukraińskie w odpowiednie ilości broni i amunicji) i to dawało pewną szansę na zjednanie ludności Ukrainy dla nowego rządu.

Jednak w tym samym czasie polski wywiad donosił o szybkiej koncentracji rosyjskich dywizji na terenach wschodniej Białorusi i - co należy podkreślić - Piłsudski był dobrze poinformowany o kierunku spodziewanego uderzenia Armii Czerwonej. Analiza raportów dokonana w polskim sztabie generalnym wykazała, że dowództwo rosyjskie przewidywało kierunek natarcia z rejonu Witebska na Mińsk i Wilno. Wojsko Polskie nie było w stanie uprzedzić tego uderzenia, ponieważ Piłsudski zadecydował - jeszcze przed rozpoczęciem kampanii wojennej - pozostawić słabo zabezpieczony front białoruski, a większość sił rzucić na Ukrainę w celu zajęcia obszaru aż do linii Dniepru z przedłużeniem w kierunku Odessy. Ryzykowny, choć dobrze opracowany, plan operacyjny przewidywał rozbicie rosyjskiej XII i XIV Armii, a dopiero potem przerzucenie większości polskich wojsk na front białoruski dla zatrzymania rosyjskiego uderzenia z północnego wschodu. Początkowo przewidywano, że rosyjskie uderzenie na Polskę rozpocznie się w lipcu, a zaczęło się już 14 maja. Liczono, że do tego czasu wyznaczone cele strategiczne na froncie ukraińskim zostaną osiągnięte i powstanie front na linii Dniepru, który będą w stanie utrzymywać trzy dywizje polskie i sześć ukraińskich. Na to wszystko strona polska miała zaledwie kilka tygodni... W tak bardzo ryzykownej sytuacji o rozstrzygnięciu kampanii zadecydować mogła tylko szybkość operacji, co stanowiło podstawowy warunek militarnego sukcesu, a tej w odpowiednim tempie naczelne dowództwo wojsk polskich - nie przeprowadziło... Ale nie wolno zapominać, że nikt nie mógł przewidzieć, że tak słaby będzie nabór ochotników do ukraińskich dywizji, tym bardziej, że ataman S. Petlura, najprawdopodobniej nie chcąc zrażać pobratymców, nie zdecydował się na pobór obowiązkowy. Wszystko to legło u podstaw całkowitej przegranej ukraińskiej kampanii ${ }^{39}$.

Piłsudski miał naturę zarówno autokraty, jak i konspiratora, i ani premier L. Skulski (tak przecież zgodny z Naczelnym Wodzem co do programu „polityki wschodniej”), ani rząd - nie zdawali sobie sprawy z powagi sytu-

39 J. Goclon, W obronie Europy..., s. 88, 89, 95-97. Po zakończeniu działań wojennych Piłsudski przyznał, że rozpoczął ofensywę ze zbyt dużym opóźnieniem, obawiając się wiosennych roztopów i było dużym błędem z jego strony, że tego nie uczynił, bo wiosna w 1920 r. zaczęła się na Ukrainie wyjątkowo wcześnie. Przekreśliło to podstawowy cel militarny operacji - całkowite zniszczenie bolszewickiej XII Armii, co tak bardzo zaciążyło na dalszych losach ukraińskiej kampanii, W. Jędrzejewicz, Front litewsko-białoruski podczas wojny 1920, „Niepodległość, t. VIII, Londyn 1972; L. Wyszczelski, Kijów 1920..., s. 100-105; por. J. Stachiewicz, Działania zaczepne 3 armii na Ukrainie, Warszawa 1925, s. 14 i in.; idem, Zarys historii wojennej formacyj polskich 1918-1920, Warszawa 1931, s. 29 i in.; S. Barlitz, Działania w obszarze Ihumenia w maju 1920 r., Warszawa 1933, s. 11 i in. 
acji - z powodu braku nawet podstawowych informacji - i po prostu nie wiedzieli o zbliżającym się niebezpieczeństwie. O upadku rządu zadecydowały sprawy ściśle krajowe; głównie spory polityczne o bierność rządu (według PSL-„,Piast”) w przeprowadzaniu reformy rolnej. Przywódca PSL, Wincenty Witos, zdecydował (8 czerwca) o wycofaniu obydwóch swoich ministrów z rządu, choć za formalny pretekst posłużyły problemy związane $\mathrm{z}$ aprowizacją kraju, tym bardziej że rząd uparcie utrzymywał politykę sekwestru, mimo znacznych niepowodzeń $\mathrm{w}$ realizacji przymusowego wykupu zboża u chłopów. 9 czerwca 1920 roku (następnego dnia polskie oddziały rozpoczęły opuszczanie Kijowa) premier złożył swoją rezygnację oświadczając, że „obecny stosunek Sejmowych Klubów Poselskich do Rządu i stanowisko ich wobec wniesionego przez Rząd projektu ustawy o sekwestrze ziemiopłodów zmusiły mnie do zgłoszenia imieniem Gabinetu dymisji" 40 . Należy podkreślić, że stanowisko prawicy było zasadniczo zbliżone do PSL-,Piast” w kwestii przywrócenia wolnego handlu artykułami rolnymi i o dymisji rządu przesądziło odrzucenie (2 czerwca) projektu rządowego o "utrzymaniu sekwestru”, a wyjście z rządu ministrów "ludowców” (8 czerwca) było jedynie finałem rozpadu koalicji ${ }^{41}$.

Podsumowując, rząd Leopolda Skulskiego funkcjonował niejako w cieniu przygotowań wojennych i zajmował się $\mathrm{w}$ dużej mierze sprawami wewnętrznymi kraju, pozostawiając właściwie politykę zagraniczną, przede wszystkim w zakresie "sprawy wschodniej” - Naczelnikowi Państwa. Gabinet funkcjonował względnie stabilnie, zajmując się niemal wyłącznie sprawami krajowymi, dopóki trwał zwycięski z pozoru, polsko-ukraiński "pochód na Kijów”, ale wszystko uległo radykalnej zmianie wraz z majowym uderzeniem Armii Czerwonej, kiedy to lawinowo rosnące zagrożenie ze strony bolszewickiej Rosji unaoczniło, że tak dramatyczny bieg wypadków, grożący utratą niepodległości, przerósł możliwości tego gabinetu, który nie był w stanie wyprowadzić kraju, z pogłębiającej się z każdym dniem, katastrofalnej sytuacji.

Nie można jednak zapominać, że w walce o niepodległość Ukrainy - co poparł rząd Leopolda Skulskiego - zmierzano również do osłabienia bolszewickiej Rosji, której Armia Czerwona niosła jedynie powszechną grabież, zbrodniczą ideologię, prowadzącą do gospodarczej ruiny, ujarzmianie i demoralizację całych narodów, a przede wszystkim - nieznane wówczas na taką skalę - ludobójstwo! Była to walka o stawkę najwyższą; o trwałe istnienie państwa polskiego ${ }^{42}$.

40 AAN, PRM, Akta grupowe; A. Paczkowski, Leopold Skulski..., s. 119, 120.

41 A. Paczkowski, Leopold Skulski..., s. 119, 120; A. Wątor, op. cit., s. 59, 60. O okolicznościach poprzedzających upadek rządu Leopolda Skulskiego, na tle społeczno-gospodarczej sytuacji kraju, więcej: K. Badziak, W oczekiwaniu na przełom. Na drodze od odrodzenia do załamania państwa polskiego: listopad 1918 - czerwiec 1920, Łódź 2004, s. 257-258; J. Goclon, Rząd Leopolda Skulskiego..., s. 200.

42 J. Goclon, Rząd Leopolda Skulskiego..., s. 201. 


\section{Bibliografia}

\section{Źródła}

Archiwum Akt Nowych w Warszawie, Prezydium Rady Ministrów, mf. 20052, t. 8; mf. 20053, t. 9; mf. 20054, t. 10.

Gostyńska W., Materiały archiwalne o tajnych rokowaniach polsko-radzieckich w Baranowiczach i Białowieży, „Z dziejów stosunków polsko-radzieckich”, Warszawa 1969, nr 4.

Sprawozdanie Stenograficzne posiedzenia Sejmu (105) 18.12.1919 r.

\section{Wspomnienia}

Babel I., Dziennik 1920, Warszawa 1990.

Romer J., Pamiętniki, Lwów 1938.

Witos W., Moje wspomnienia, t. II, cz. 2, Warszawa 1990.

\section{Opracowania}

Albert A. (W. Roszkowski), Najnowsza Historia Polski, cz. 1, 1918-1939, Warszawa 1983 (II obieg).

Badziak K., W oczekiwaniu na przełom. Na drodze od odrodzenia do załamania państwa polskiego: listopad 1918 - czerwiec 1920, Łódź 2004.

Barlitz S., Działania w obszarze Ihumenia w maju 1920 r., Warszawa 1933.

Benedykt S., Kijowskie „poprawki historyczne”, "Zeszyty Historyczne”, Paryż 1975.

Carr E. H., The Bolshevik Revolution, Londyn 1966.

Cat-Mackiewicz S., Historia Polski, Wrocław 1989 (II obieg), cz. 1.

Ciołkosz A., Koniec monolitu, Londyn 1964.

Conquest R., Lenin. Prawda o wodzu rewolucji, Warszawa 1993.

Conquest R., Stalin, Warszawa 2000.

Cygan J., Wysocki W. J., Niepodległość była nagrodą: polski wysiłek zbrojny w latach 1914-1921, Warszawa 1999.

Czarna ksiega komunizmu. Zbrodnie, terror, prześladowania, Warszawa 1999.

D’Abernon E. V., Osiemnasta decydująca bitwa w dziejach świata pod Warszawa 1920 roku, Warszawa 1990.

Davies N., Orzeł biały. Czerwona gwiazda. Wojna polsko-bolszewicka 1919-1920, Kraków 1997.

Deruga A., Początek rokowań o sojusz między Piłsudskim a Petlura (styczeń - lipiec 1919), t. VI: Z dziejów stosunków polsko-radzieckich, 1970.

Galuba R., Pertraktacje polityczno-wojskowe między Polskq a Ukraińska Republikg Ludowa (lipiec - sierpień 1919 roku), „Mars” 1994, t. 2. 
Goclon J., Rząd Ignacego Paderewskiego. Geneza, skład osobowy i działalność (16.01 9.12.1919 r.), „Acta Universitatis Lodziensis, Folia Historica” 2011, 85.

Goclon J., Rząd Leopolda Skulskiego (13 XII 1919 - 9 VI 1920), skład, działalność i jego polityka wschodnia (zarys problemu), „Acta Universitatis Lodziensis, Folia Historica" 2012, 88.

Goclon J., W obronie Europy. Wojna z bolszewicka Rosja w 1920 roku, Komorowo 2012.

Jaczyński S., Generalicja obu walczących stron. Próba charakterystyki i oceny, [w:] Rok 1920. Z perspektywy osiemdziesięciolecia, Warszawa 2001.

Jaskólski M., Władze administracyjne Łodzi do 1939 roku, Łódź 2001.

Jędrzejewicz W., Front litewsko-białoruski podczas wojny 1920, „Niepodległość”, t. VIII, Londyn 1972.

Jędrzejewicz W., Rokowania borysowskie w 1920 roku, „Niepodległość”, t. 3, Londyn 1951.

Johnson P., Historia Świata (od 1917 r.), Londyn 1989.

Kaszczyk-Grodzicka D., Farmaceuta łódzki Leopold Skulski, polityk, społecznik i mąż stanu II Rzeczypospolitej Polskiej, „Wędrownik” 1990, nr I-III.

Klimecki M., Wojna czy pokój? Polsko-ukraińskie negocjacje 1918-1921, [w:] Polska i Ukraina: sojusz 1920 roku i jego następstwa, red. W. Rezner, E. Wiszka, Z. Karpus, Toruń 1997.

Koko E., Polska Partia Socjalistyczna i Józef Piłsudski wobec kwestii ukraińskiej w latach 1918-1920, „Dzieje Najnowsze” 1989, z. 1.

Kosicka, A., Gabinet Paderewskiego, [w:] Gabinety Drugiej Rzeczypospolitej, red. J. Faryś, J. Pajewski, Szczecin - Poznań 1991.

Kot Ł., Leopold Skulski. Premier z Zamościa 1877-1939, Zamość 2007.

Kowalski Z. G., Wojna polsko-bolszewicka na łamach polskich fachowych periodyków wojskowych z lat 1919-1939, Torun 2002.

Księga Czerwona. Zbiór dokumentów dyplomatycznych o stosunkach Rosji i Polski od 1918 do 1920 r., Moskwa 1921.

Kto byt kim w Drugiej Rzeczypospolitej, red. J. M. Majchrowski, t. 1, Warszawa 1994.

Kuczerepa M., Układ Warszawski z 1920 roku: geneza, problemy, następstwa, [w:] Rok 1920. Z perspektywy osiemdziesięciolecia, Warszawa 2001.

Kumaniecki J., Dwa oblicza dyplomacji radzieckiej. Rokowania w Mińsku i Rydze, [w:] Wojna polsko-sowiecka 1920 roku. Przebieg walk i tło międzynarodowe, Warszawa 1991.

Kutrzeba S., Polska Odrodzona 1914-1939, Kraków 1988.

Leinwand A., Ruch w obronie Rosji Radzieckiej podczas wojny polsko-radzieckiej 1920 r., „Biuletyn Akademii Wojskowo-Politycznej im. F. Dzierżyńskiego” 1957.

Lenin W. I., Co to jest internacjonalizm?, Warszawa 1982.

Lewandowski J., U źródeł wyprawy kijowskiej, "Zeszyty Naukowe WAP” 1962, nr 7.

Macfarlane L. J., Hands off Russia, „Past and Present” 1967.

Malinowski J. C., Zarys myśli politycznej Józefa Piłsudskiego, Kraków 1989. 
Miedziński B., Polityka wschodnia Piłsudskiego, „Zeszyty Historyczne”, Paryż 1975, nr 32.

Od Moraczewskiego do Składkowskiego. Gabinety Polski Odrodzonej 1918-1939, red. J. Faryś, A. Wątor, H. Walczak, Szczecin 2010.

Ostoja-Owsiany A., Rok 1920 w krzywym zwierciadle propagandy $i$ w rzeczywistości, Warszawa 1981 (II obieg).

Paczkowski A., Leopold Skulski, premier Republiki Polskiej 13 X 1919 - 9 VI 1920, [w:] Prezydenci i premierzy Drugiej Rzeczypospolitej, Wrocław 1992.

Paczkowski A., Prasa polska w latach 1918-1939, Warszawa 1980.

Paduszek K., Działalność propagandowa służb informacyjno-wywiadowczych Wojska Polskiego w czasie wojny polsko-bolszewickiej 1919-1921, Torun 2004.

Pajewski J., Stanisław Patek (16 XII 1919 - 9 VI 1920 r.), [w:] Ministrowie Spraw Zagranicznych (1919-1939), red. J. Pajewski, Szczecin 1991.

Pepłoński A., Wywiad w wojnie polsko-bolszewickiej 1919-1920, Warszawa 1999.

Pobóg-Malinowski W., Najnowsza historia polityczna Polski, t. 2 (1914-1939), Warszawa 2000.

Polski słownik biograficzny, Warszawa 1990.

Polski wywiad wojskowy, red. P. Kołakowski, A. Pepłoński, Torun 2006.

Pragier A., Czas przeszły dokonany, Londyn 1966.

Pronobis W., Polska i świat w XX wieku, Warszawa 1991.

Prus E., Hulajpole. Burzliwe dzieje kresów ukrainnych (od stowiańskiego świtu do Cudu nad Wista), Wrocław 2003.

Romer J., Sprawa generała Jana Romera, lipiec 1920 - czerwiec 1921, „Niepodległość”, t. 25, Londyn 1992.

Rychlikowa I., Ziemiaństwo polskie 1772-1944. Dzieje degradacji klasy, „Dzieje Najnowsze" 1985, R. 17, nr 2.

Sieradzki J., Białowieża i Mikaszewicze. Mity i prawdy. Do genezy wojny pomiędzy Polska a RSFRR w 1920 r., Warszawa 1959.

Skaradziński B., Polskie lata 1919-1920, t. 2, Warszawa 1993.

Skwarczyński J., Kampania polsko-ukraińska. Doświadczenia operacyjne i bojowe, Lwów 1921.

Smaga J., Rosja w 20 stuleciu, Kraków 2001.

Spahr W. J., Generałowie Stalina, Warszawa 2001.

Srokowski K., Elita bolszewicka. Studium socjologiczne, Kraków 1927.

Srokowski K., Na czerwonym Olimpie, Lwów 1934.

Stachiewicz J., Działania zaczepne 3 armii na Ukrainie, Warszawa 1925.

Stachiewicz J., Zarys historii wojennej formacyj polskich 1918-1920, Warszawa 1931.

Stobiecki R., Bolszewizm a historia: próba rekonstrukcji bolszewickiej filozofii dziejów, Łódź 1998.

Suchcitz A., Generałowie wojny polsko-sowieckiej 1919-1920. Mały słownik biograficzny, Białystok 1993. 
Suleja W., Józef Piłsudski, Wrocław 1997.

Szajdak S., Polsko-Ukraiński sojusz polityczno-wojskowy w 1920 roku, Warszawa 2005.

Szaposznikow B., Warszawskaja operacja, Moskwa 1933.

Teslar T., Polityka Rosji Sowieckiej podczas wojny z Polską: trzy momenty, Warszawa 1937.

Topolski J., Historia Polski, Warszawa 1994.

Torzecki R., Kwestia ukraińska w Polsce w l. 1923-1929, Kraków 1989.

Wandycz P., Nieznane listy Petlury do J. Piłsudskiego, "Zeszyty Historyczne”, Paryż 1965, nr 8.

Wandycz P., Z zagadnień wspótpracy polsko-ukraińskiej w latach 1919-1920, "Zeszyty Historyczne", nr 12, Paryż 1967.

Wiliams B., Lenin, Wrocław 2002.

Wołkogonow D., Lenin, prorok raju, apostoł piekła, Warszawa 2006.

Wrzosek M., Wojny o granice Polski Odrodzonej: 1918-1920, Warszawa 1992.

Wyszczelski L., Kijów 1920, Warszawa 1999.

Zaremba P., Historia Dwudziestolecia (1918-1939), t. 1, Paryż 1981.

Żenczykowski T., Dwa komitety 1920 1944. Polska w planach Lenina i Stalina: szkic historyczny, Warszawa 1990. 